\title{
Effectiveness of the Zero Interest Rate Policy for Financial Markets in Japan: Principal Components Analysis
}

\author{
Yutaka Kurihara $^{1}$ \\ ${ }^{1}$ Department of Economics, Aichi University, Nagoya, Japan \\ Correspondence: Department of Economics, Aichi University, 4-60-6 Hiraike, Nakamura, Nagoya, 4538777, Japan.
}

Received: March 29, 2016

Accepted: April 5, 2016

Available online: April 8, 2016

doi:10.11114/aef.v3i3.1532

URL: http://dx.doi.org/10.11114/aef.v3i3.1532

\begin{abstract}
The zero interest policy was introduced by the Bank of Japan (BOJ) and kept in force from February 12, 1999 through August 11, 2000, after which the BOJ introduced the quantitative easing policy in March 19, 2001. On March 9, 2006, the BOJ exited quantitative easing amid signs that deflation was ending and the recession had disappeared. After that, the zero interest rate policy again was introduced. Quantitative easing policies has been examined a lot in the literature; however, the BOJ introduced Abenomics, an unprecedented, aggressive monetary policy, on April 4, 2013. The effectiveness of the monetary policy during the zero interest rate policy era has not been adequately discussed. This article focuses on daily Japanese stock prices during the zero interest rate era; employs a principal components analysis to determine the effectiveness of the policy; and shows domestic interest rates, US interest rates, US and China stock prices, and the exchange rate of yen/US dollar influence Japanese stock prices but that the yen/Euro exchange rate does not.
\end{abstract}

Keywords: central bank; monetary policy; stock price, zero interest rate policy

\section{Introducation}

Deflationary pressure has had a serious impact on some developed countries since the 1990s. Worldwide financial shocks impacted the world economy and affected many countries, including both developing and newly industrializing economies. Policymakers, namely central banks, have tried to overcome the situation; however, most developed countries suffered recession. In response to this situation, on February 12, 1999, the Bank of Japan (BOJ), the Japanese central bank, implemented the unprecedented zero interest rate policy to combat deflation and to boost the economy. This tactic can be understood as sending money to the economy, promoting increases in asset prices, and removing deflationary pressures. On August 11, 2000, the zero interest rate policy in Japan was rescinded, as the economic situation showed signs of recovery. However, as Japan recovery had been less than adequate, after a long trial under the low interest rate policy, the BOJ changed the policy and conducted a more drastic monetary policy known as quantitative monetary easing,. The unprecedented policy started on March 19, 2001, and ended on March 9, 2006.

After the subprime problems in 2007 and the Lehman shock in 2008, a huge amount of capital flowed into the Japanese financial markets in spite of the fact that the Japanese economy still was not in good condition. Not only Japan but also Switzerland had to accept a lot of money all over the world. The Japanese yen appreciated against other currencies, which hit the Japanese economy as the strong yen dampened exports. In October 2010, the BOJ introduced its comprehensive monetary easing policy to respond to the re-emergence of deflation and a slowing recovery. One key measure was an asset purchase program that involved government bonds as well as private assets. After that, the Japanese government changed and more aggressive fiscal policy was strongly demanded. The zero interest rate policy was in effect beginning in October 2010 and continues in force now.

In Japan, a drastic new policy, called Abenomics (for Abe, the prime minister), was adopted in 2013. The Japanese government not only implemented drastic fiscal policy but also took measures to strengthen competitiveness and economic growth. Japan has been under severe economic conditions, namely, deflation. These measures included possible policy actions to reform the economic structure, such as concentrating resources on innovative research and development, strengthening the foundation for innovation, performing regulatory and institutional reforms, and changing the tax system (increasing the consumption tax and reducing the corporate tax). Moreover, by strengthening coordination between the BOJ and the government, since 2013, the Japanese government has implemented measures to 
achieve a new fiscal structure to ensure the credibility of the fiscal condition. The BOJ introduced Abenomics, an unprecedented aggressive monetary policy, on April 4, 2013. Much discussion has taken place about Abenomics; however, few studies have examined the zero interest rate policy and stock prices in spite of its importance. The so-called Abenomics have been highly evaluated in Japan. Asset prices, especially stock prices, have risen sharply since the beginning of 2013. Export industries, including Toyota (automobile company), have announced record high profits as the yen has depreciated against other currencies. However, the Japanese economy still remains weak. Exports and industrial production have decreased, reflecting worse overseas economies. Fixed investments also have shown some weakness. Consumption has remained resilient. The year-on-year rate of change in the CPI is still about $0 \%$.

Ruge-Murcia (2006) indicated that when zero low bound is considered in the markets, the hypothesis of expectations for the yield spread creates a nonlinear relationship between changes in short-term and long-term interest rates. As the short-term interest rate becomes zero, the sensitivity of long-term interest rates with regard to short-term interest rates declines. This response becomes asymmetric with short-term rate increases along with larger absolute long-term interest rate movement rather than decreases in the short-term. Grisse (2015) found that the extent to which these nonlinearities is informative about the transmission of short-term rates changes to long-term ones.

As the exchange rate premium model or portfolio approach model for exchange rate determination models has prevailed, the existence of premium foreign exchange markets has been analyzed. It is of course related strongly to interest rates. Bhar, Chiarella, and Pham (2001) provided evidence that the forward risk is stationary and has substantial time variation. Wu (2007) showed empirical results that reject the restrictions on the exchange rate and interest rate imposed by the term structure of interest rates. Azouzi, Kumar, and Aloui (2011) found that the forward premium is crucial for short-term calculations. Using data from six countries, Kim (2013) indicated that pricing revision errors exist in the exchange rate risk premium.

Recently, expansion of the traditional premium models has been ongoing. Arminio (1986) provided a theoretical model for how the risk premium relates to international shares of foreign assets and wealth, as well as the variance-covariance matrix of prices and exchange rates. Beng and Siong (1993) showed that forward discounts of exchange rates reflect expectations of future changes in exchange rates, and expectations of the financial market are not rational. Basurto and Ghosh (2001) indicated that there is little evidence that real interest rates contribute to a large risk premium. Landcon and Smith (2003) denied the rational expectations hypothesis and found the existence of a time-varying risk premium. Corte and Tsiakas (2009) showed that risk-averse market participants prefer to pay a high fee to switch from a dynamic portfolio decision based on the random walk model to the decision that hinges on the forward premium with stochastic volatility model. Alain and Carmelo (2015) found that pricing errors from ignoring the term structure of interest rates is smaller than the error that results from omission of the foreign exchange risk. Breoll, Welzel, and Wong (2015) showed that uncovered interest rate parity did not hold when international firms had a risk-averse attitude.

Estrella and Mishkin (1996) showed that empirical results depend on macroeconomic variables. Also, Kim and Singleton (2012) showed that a variety of non-negative symmetric term structure models lead to various predictions regarding the behavior of longer-term yields around the zero or low bound. De Pace (2013) showed that the term structure is not a credible predictor of economic growth.

The relationship between stock prices and macroeconomic variables has been discussed all over the world. Campbell (1987, 1991), Campbell and Shiller (1998), Cutler, James, and Summers (1989), Fama and Schwert (1997), Hodrick (1992), and Keim and Stambaugh (1986) showed that short- and long-term interest rates have a modest degree of forecasting power for excess stock returns. Similarly, other studies, such as Campbell and Shiller (1991) and Fama (1984), have shown that the slope of the term structure of interest rates makes it possible to forecast excess stock returns.

On the other hand, Campbell and Ammer (1993) and Hamori and Honda (1996) showed that short-term interest rates impact stock prices. During the 1980s and 1990s, many researchers analyzed the relationship between stock prices and interest rates.

Black Monday occurred in 1987 in the United States. At that time, international interdependence of stock prices received much attention, which prompted studies by Eun and Shim (1989), Jeon and Chiang (1991), Lai, Lai, and Fang (1993), Chowdhury (1994), and Hirayama and Tsutsui (1998). Liow, Muhammad, and Huang (2006) showed that the expected risk premium and the conditional volatilities of the risk premia on property stock are time-varying and dynamically related to the conditional volatilities of macroeconomic determinants. However, few recent studies have examined this topic. Meric (2012) showed that US stock markets have large impacts on the European and Australian stock markets. Also, Meric, Kimb, Geng, and Meric (2012) indicated that Singapore, Indian, and Japanese stock markets are the most influential markets and the Philippine and South Korean stock markets are the least influential stock markets in Asia. Mazuruse (2014) found that stock returns in Zimbabwe are most largely influenced by changes in 
consumer prices, money stocks, exchange rates, and treasury bills. Pradhan, Arvin, Norman, and Hall (2014) showed that banking sector maturity and stock market maturity are linked.

Little research exists on the effect of the exchange rate on stock prices. Hamao (1988) investigated this relationship and found that the exchange rate was not significant for Japan, but Choi, Hiraki, and Takezawa (1998) showed that the exchange rate is an important factor. Homma, Yoshiro, and Tsutsui (2005) stated that stock investors evaluate firms' foreign asset positions and respond to changes in the exchange rate. Demarzo and Duffie (1995), Barton (1996), Brown (2001), and Pincus and Rajgopal (2003) argued that hedging using financial derivatives can reduce the amount of noise in corporate earnings. Since the 1980s, capital movement across countries has been dramatic. In spite of the reduction in fluctuations of the exchange rate in the 1990s compared to the 1980s, the capital movement should not be ignored. Since the middle of the 2000s, exchange rate instability has been common. There is some possibility that exchange rates have been influencing Japanese stock prices.

In the fields of economics, few studies have employed principal components analysis. Moreover, few existing studies have analyzed monetary policy. On the other hand, this method can decompose the variables that examine economic phenomena into common and specific components.

This article examines whether or not the zero interest rate policy was effective. The sample period is from October 5, 2010, to April 3, 2013, namely, during the time of the zero interest rate policy. Japanese stock prices are focused to judge whether or not the zero interest rate policy was effective. Along with regression analysis, principle component analysis is used.

Empirical methods are explained in section 2. Section 3 show the empirical analyses and the results. Further empirical analyses are the performed and the results examined. Finally, this article ends with a brief summary.

\section{Theoretical Background and Empirical Method}

\subsection{Theoretical background}

Principal components analysis is a statistical method for clearing a smaller number of uncorrelated variables, namely, principal components, from a large set of data. The goal of this analysis is to check the maximum amount of variance with the fewest number of principal components. This method combines the techniques of principal component analysis to decompose the variables that examine economic phenomena into common and specific components. One can use this analysis to reduce the number of variables and avoid multicollinearity or when there are many variables relative to the number of observations.

\subsection{Data and empirical method}

The data used in this paper are interest rates (Japanese call rate, Japanese long-term rate [10 years], and FF), stock prices (Nikkei [Japan], S\&P, DOW, DAX [Germany], and SHASHR [China]), exchange rates (yen/US dollar and yen/Euro), and oil prices (Japan). Daily data are used for estimation.

First, correlation of each variable is estimated and estimation of a country model is performed by reduced form with 11 endogenous variables, in addition to a constant and a linear trend is performed. The first principal component of variables that represent economic activity, the common component, is obtained and $80 \%$ of the variance, indicating the common existence of a common component, is employed.

\section{Results and Implications}

The empirical results are shown in Table 1 and Figure 1. For scree plots, order 2 is selected. 
Table 1. Eigenvalues, Eigenvectors, and Correlations

\begin{tabular}{|c|c|c|c|c|c|c|c|c|c|c|}
\hline & & & & & Eigenvalues & & & & & \\
\hline & & & & $\begin{array}{l}\text { Cum- } \\
\text { ulative }\end{array}$ & $\begin{array}{l}\text { Cum- } \\
\text { ulative }\end{array}$ & & & & & \\
\hline Number & Value & $\begin{array}{c}\text { Dif- } \\
\text { ference }\end{array}$ & $\begin{array}{c}\text { Pro- } \\
\text { portion }\end{array}$ & Value & $\begin{array}{c}\text { Pro- } \\
\text { portion }\end{array}$ & & & & & \\
\hline 1 & 5.032 & 1.181 & 0.457 & 5.032 & 0.457 & & & & & \\
\hline 2 & 3.851 & 2.732 & 0.350 & 8.883 & 0.800 & & & & & \\
\hline 3 & 1.118 & 0.597 & 0.101 & 10.008 & 0.909 & & & & & \\
\hline 4 & 0.520 & 0.287 & 0.047 & 10.525 & 0.956 & & & & & \\
\hline 5 & 0.233 & 0.104 & 0.021 & 10.755 & 0.977 & & & & & \\
\hline 6 & 0.128 & 0.070 & 0.011 & 10.883 & 0.989 & & & & & \\
\hline 7 & 0.058 & 0.032 & 0.005 & 10.942 & 0.994 & & & & & \\
\hline 8 & 0.025 & 0.006 & 0.002 & 10.967 & 0.997 & & & & & \\
\hline 9 & 0.018 & 0.007 & 0.001 & 10.986 & 0.998 & & & & & \\
\hline 10 & 0.011 & 0.009 & 0.001 & 10.998 & 0.999 & & & & & \\
\hline 11 & 0.001 & --- & 0.000 & 11.000 & 1.000 & & & & & \\
\hline & & & & Eigen & ectors (loa & ings): & & & & \\
\hline Variable & PC 1 & PC 2 & PC 3 & $\mathrm{PC} 4$ & PC 5 & PC 6 & PC 7 & PC 8 & PC 9 & PC 10 \\
\hline _10YINT & -0.135 & 0.467 & 0.087 & -0.013 & 0.029 & 0.484 & 0.616 & 0.207 & 0.282 & 0.126 \\
\hline CALL & 0.119 & 0.444 & 0.266 & -0.077 & -0.136 & -0.778 & 0.256 & 0.048 & 0.046 & -0.127 \\
\hline DOW & 0.359 & -0.275 & 0.196 & 0.059 & -0.171 & -0.002 & -0.030 & 0.175 & 0.511 & 0.107 \\
\hline DAX & 0.376 & -0.256 & 0.069 & 0.127 & -0.013 & 0.014 & 0.402 & 0.380 & -0.659 & 0.160 \\
\hline EXCEU & 0.299 & 0.308 & 0.146 & -0.380 & 0.545 & 0.122 & -0.401 & 0.396 & -0.057 & -0.117 \\
\hline EXCUS & 0.404 & 0.133 & -0.196 & -0.311 & 0.120 & -0.027 & 0.080 & -0.529 & -0.011 & 0.617 \\
\hline OIL & -0.131 & -0.118 & 0.865 & 0.107 & 0.218 & 0.111 & -0.009 & -0.355 & -0.108 & 0.097 \\
\hline $\mathrm{FF}$ & 0.177 & 0.419 & 0.167 & 0.091 & -0.678 & 0.274 & -0.399 & 0.004 & -0.228 & 0.089 \\
\hline S_P & 0.376 & -0.258 & 0.142 & 0.011 & -0.122 & 0.009 & -0.006 & 0.180 & 0.383 & 0.055 \\
\hline STOCKJ & 0.440 & 0.001 & -0.038 & -0.081 & -0.029 & 0.230 & 0.226 & -0.420 & -0.038 & -0.716 \\
\hline SHA & 0.245 & 0.269 & -0.139 & 0.840 & 0.338 & -0.043 & -0.110 & -0.077 & 0.072 & 0.041 \\
\hline & & & & & & & & & dinary & rrelations: \\
\hline & _10YINT & CALL & DOW & DAX & EXCEU & EXCUS & OIL & $\mathrm{FF}$ & S_P & STOCKJ \\
\hline _10YINT & 1.000 & & & & & & & & & \\
\hline CALL & 0.705 & 1.000 & & & & & & & & \\
\hline DOW & -0.721 & -0.193 & 1.000 & & & & & & & \\
\hline DAX & -0.699 & -0.193 & 0.965 & 1.000 & & & & & & \\
\hline EXCEU & 0.366 & 0.730 & 0.214 & 0.241 & 1.000 & & & & & \\
\hline EXCUS & -0.052 & 0.423 & 0.529 & 0.594 & 0.803 & 1.000 & & & & \\
\hline OIL & -0.033 & -0.046 & 0.070 & -0.060 & -0.190 & -0.524 & 1.000 & & & \\
\hline $\mathrm{FF}$ & 0.648 & 0.858 & -0.059 & -0.063 & 0.701 & 0.503 & -0.170 & 1.000 & & \\
\hline S_P & -0.705 & -0.170 & 0.994 & 0.975 & 0.267 & 0.593 & -0.001 & -0.036 & 1.000 & \\
\hline STOCKJ & -0.282 & 0.240 & 0.780 & 0.823 & 0.665 & 0.917 & -0.328 & 0.390 & 0.823 & 1.000 \\
\hline SHA & 0.293 & 0.524 & 0.140 & 0.238 & 0.544 & 0.543 & -0.355 & 0.615 & 0.170 & 0.511 \\
\hline
\end{tabular}


Scree Plot (Ordered Eigenvalues)

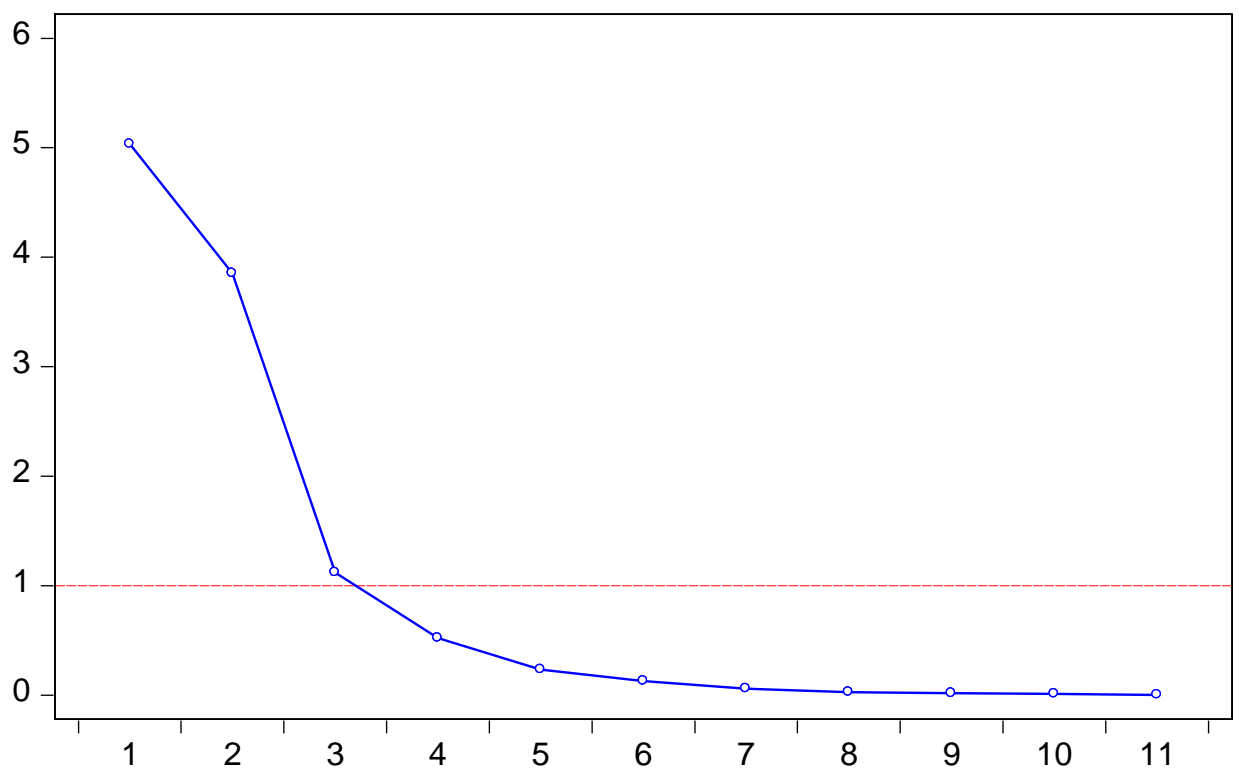

Figure 1. Scree plot.

\section{Orthonormal Loadings}

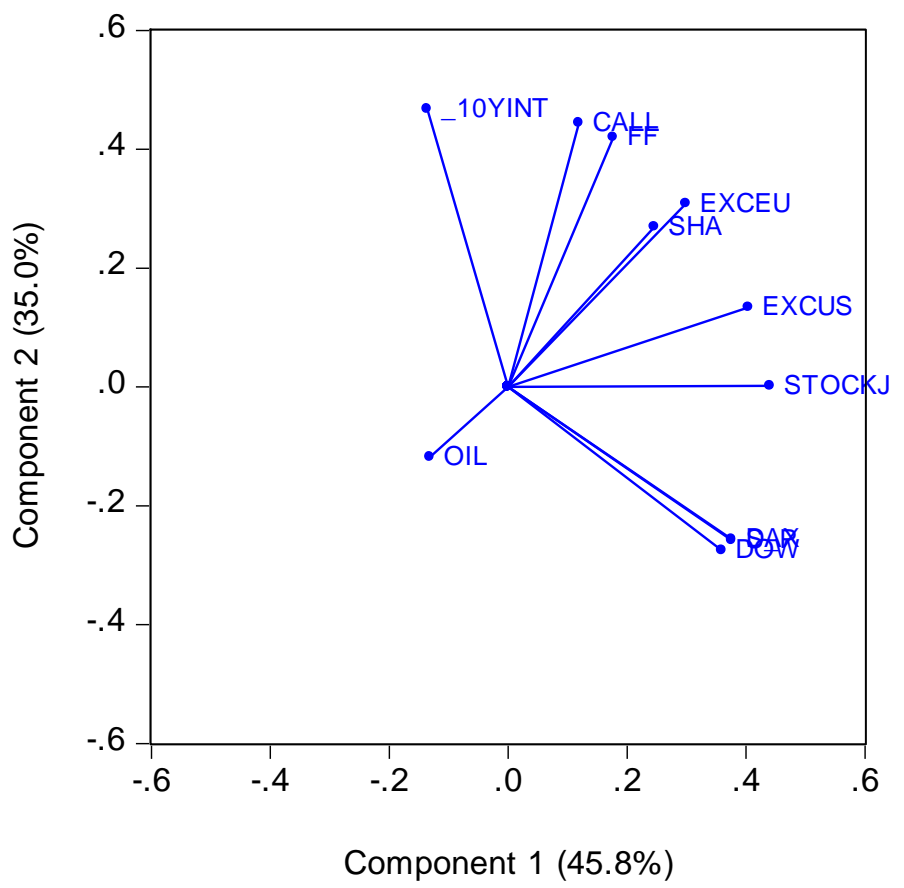

Figure 2. Orthonormal loadings.

The results show that Japanese stock prices are linked to domestic interest rates, US interest rates, US and Chinese stock prices, and exchange rate of yen/US dollar.

Moreover, regression analyses are performed. Adding to the standard OLS method, GMM (generalized method of moments) and robust estimation are also used for estimation. The GMM estimators are known to be consistent, asymptotically normal, and efficient among all estimators that do not use any extra information aside from that contained in the moment conditions. Robust estimation is unlike maximum likelihood estimation. OLS estimates for regression are sensitive to the observations that do not follow the pattern of the other observations. This is not a problem 
if the outlier is simply an extreme observation from the tail of a normal distribution; however, if the outlier is from non-normal measurement error or some other violation of standard OLS, it compromises the validity of the regression results if a nonrobust regression method is employed.

The results are shown in Table 2.

Table 2. Regression Analysis

\begin{tabular}{|c|c|c|c|c|}
\hline & OLS & OLS & GMM & Robust estimation \\
\hline & -11265.63 & -11373.363 & -12203.35 & -11656.65 \\
\hline \multirow[t]{2}{*}{$\mathrm{C}$} & $(-38.880)$ & $(-62.040)$ & $(-25.593)$ & $(-61.482)$ \\
\hline & 1417.263 & 1452.211 & 1735.536 & 1560.734 \\
\hline \multirow[t]{2}{*}{ _10YINT } & (14.104) & $(17.277)$ & (7.736) & (17.954) \\
\hline & -2650.222 & -2613.205 & -2686.362 & -2675.853 \\
\hline \multirow[t]{2}{*}{ CALL } & $(-14.802)$ & $(-17.420)$ & $(-8.281)$ & $(-17.247)$ \\
\hline & -0.078 & & & \\
\hline \multirow[t]{2}{*}{ DOW } & $(-1.274)$ & & & \\
\hline & 0.448 & 0.451 & 0.523 & 0.463 \\
\hline \multirow[t]{2}{*}{ DAX } & (12.674) & (13.172) & (6.498) & (13.079) \\
\hline & -1.235 & & & \\
\hline \multirow[t]{2}{*}{ EXCEU } & $(-0.585)$ & & & \\
\hline & 136.550 & 134.669 & 138.511 & 135.521 \\
\hline \multirow[t]{2}{*}{ EXCUS } & (32.577) & (97.348) & $(32.885)$ & (94.723) \\
\hline & 1.352 & & & \\
\hline \multirow[t]{2}{*}{ OIL } & (1.008) & & & \\
\hline & 270.726 & 262.689 & $119.714 * *$ & 220.637 \\
\hline \multirow[t]{2}{*}{ FF } & (13.480) & (14.428) & (2.436) & (11.717) \\
\hline & 4.503 & 3.941 & 3.585 & 3.911 \\
\hline \multirow[t]{2}{*}{ S_P } & $(8.315)$ & (21.085) & (8.022) & $(20.232)$ \\
\hline & 0.196 & 0.188 & 0.281 & 0.217 \\
\hline SHA & (8.827) & (8.982) & $(4.785)$ & $(10.027)$ \\
\hline Adj.R2 & 0.981 & 0.981 & 0.979 & \\
\hline Rw-squared & & & & 0.984 \\
\hline \multirow[t]{2}{*}{ F-statistic } & 10268.36 & 14676.01 & & \\
\hline & $(0.000)$ & $(0.000)$ & & \\
\hline Rn-squared & & & & 95606.47 \\
\hline statistic & & & & $(0.000)$ \\
\hline $\begin{array}{l}\text { Durbin-Watson } \\
\text { stat }\end{array}$ & 0.128 & 0.128 & 0.118 & \\
\hline \multirow[t]{2}{*}{ J-statistic } & & & 107.848 & \\
\hline & & & $(0.000)$ & \\
\hline
\end{tabular}

Note. Figures in parentheses are t-statistic, except for the z-statistic for robust estimation and probability for F- and J-statistics.

The results coincide with the results of the principle component analysis. Moreover, the impulse response function is calculated. 
Response to Cholesky One S.D. Innovations \pm 2 S.E.

Response of STOCKJ to EXCUS

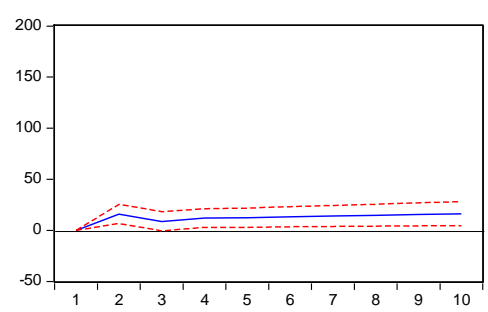

Response of EXCUS to STOCKJ

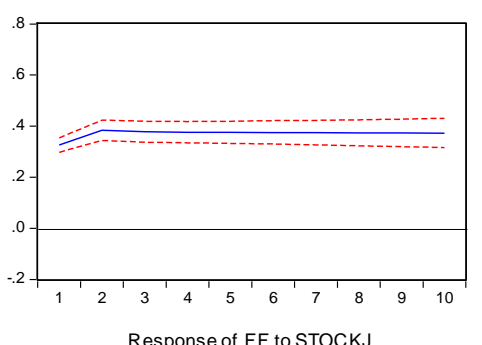

Response of FF to STOCK

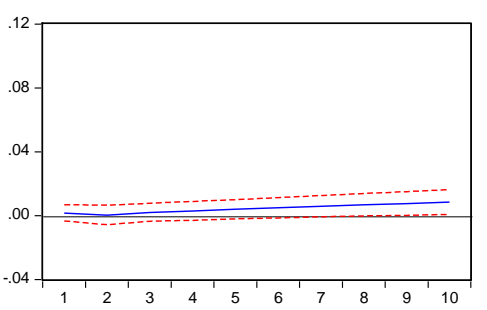

Response of S_P to STOCKJ

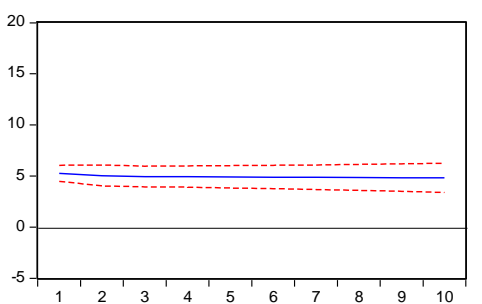

Response of STOCKJ to FF

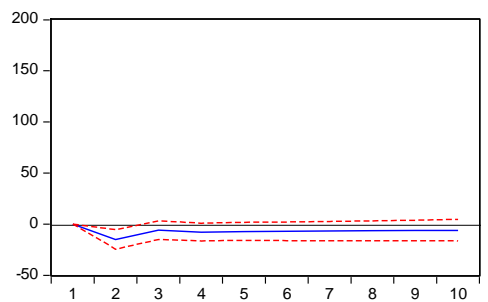

Response of EXCUS to FF

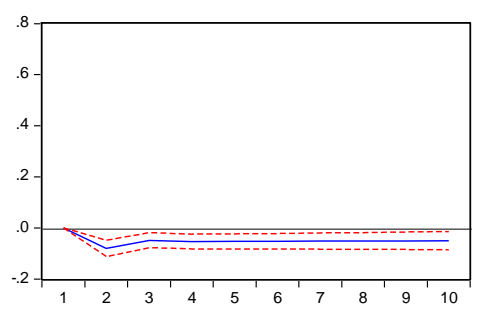

Response of FF to EXCUS

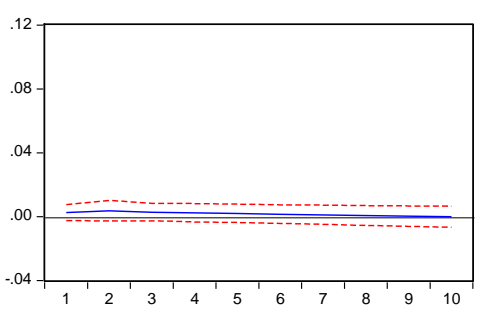

Response of S_P to EXCUS

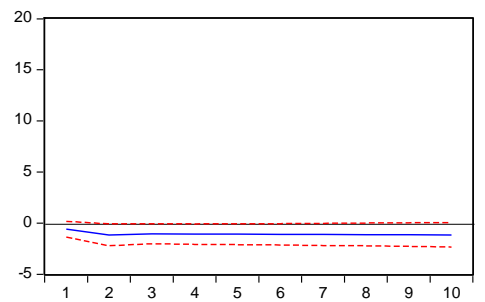

Response of STOCKJ to S P

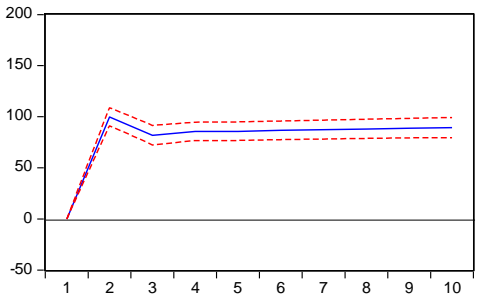

Response of EXCUS to S_P
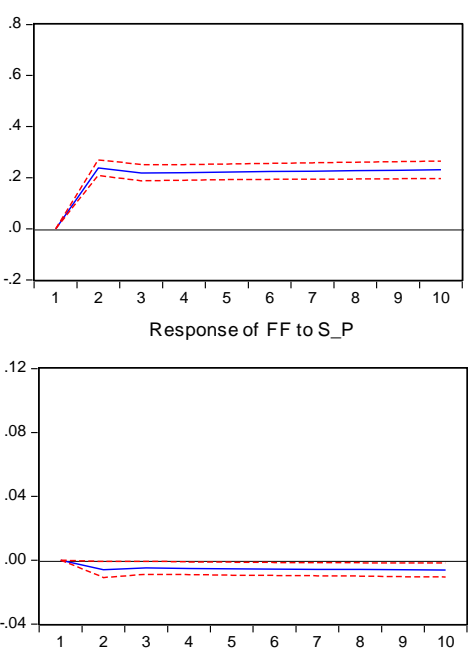

Response of S_P to FF

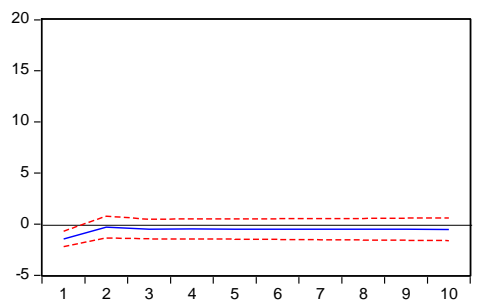

Figure 2. Impluse resonse function.

The US stock prices rose, Japanese stock prices increased the next day, and the influence continues for some time. The effect on Japanese stock prices is similar to that in the exchange rate of yen/US dollar. Depreciation of the yen and increases other countries' stock prices make Japanese stock rises rise and the effect continues for some time.

For interest rates, domestic short-term interest rates impact stock prices negatively as expected; however, domestic long-term interest rates and foreign interest rates positively impact Japanese stock prices. Also the effects continue for some time as in the regression analyses.

\section{Conclusions}

This article focuses on the zero interest rate policy era in Japan and employs principal components analysis in addition to regression analyses to examine whether or not this policy was effective for domestic stock prices. The results showed that domestic interest rates, US interest rates, US and Chinese stock prices, and the yen/US dollar exchange rate influence Japanese stock prices; however, the yen/Euro exchange rate does not.

Japan conducted unprecedented and more aggressive monetary policy, quantitative easing and qualitative and quantitative monetary policy. From April 2013, Abenomics was implemented, and the yen deprecated greatly and stock prices rose largely. However, it should be noted that during the zero interest rate policy era, stock prices rose slightly but significantly as expected.

Certainly stock prices are determined by many factors and the factors change always and continuously. It is important to examine whether or not monetary policy was effective during not only the quantitative easing era but also during the era of the zero interest rate policy. Further research is needed for analyses. 


\section{Acknowledgements}

I thank two reviewers for their valuable comments and suggestions. This work was supported by JSPS KAKENHI Grant Number $15 \mathrm{H} 03366$.

\section{References}

Alain, K., \& Carmelo, G. (2015). Foreign exchange rate risk and the term-structure of industry costs of equity. Journal of International Money and Finance, 51(1), 71-88. http://dx.doi.org/10.2139/ssrn.1911865

Arminio, F (1986). Price uncertainty and the exchange-rate risk premium. Journal of International Economics, 20(1-2), 179-185.

Azouzi, D., Kumar, R. V., \& Aloui, C. (2011). Forward rate unbiasedness hypothesis in the Tunisian exchange rate market. International Journal of Academic Research in Business and Social Sciences, 1(2), 17-44. http://dx.doi.org/10.2139/ssrn.1696385

Barton, R. J. (1996). Does the use of financial derivatives affect earnings management decisions? Accounting Review, $76,1-26$.

Basurto, G., \& Ghosh, A (2001). The interest rate-exchange rate Nexus in currency crises. IMF Staff Papers, suppl. IMF Annual Research Conference 2001, 47, 99-120.

Beng, G. W., \& Siong, W. K. (1993). Exchange rate expectations and risk premium in the Singapore/US dollar exchange rate: Evidence from survey data. Applied Financial Economics, 3(4), 365-373.

Bhar, R., Chiarella, C., \& Pham, T. (2001). Modeling the currency forward risk premium: A new perspective. Asia-Pacific Financial Markets, 8(4), 341-360. http://10.1023/A:1020643612751

Breoll, U., Welzel, P., \& Wong, K. P. (2015). Exchange rate risk and the impact of regret on Trade. Open Economics Review, 26(1), 109-119. http://10.1007/s11079-014-9321-0

Brown, G. W. (2001). Managing foreign exchange risk with eerivatives. Journal of Financial Economics, 60, 401-448. http://10.1016/S0304-405X(01)00049-6

Campbell, J. Y. (1987). Stock returns and the term structure. Journal of Financial Economics, 18, 373-399.

Campbell, J. Y. (1991). A variance decomposition for stock returns. Economic Journal, 101, 157-179.

Campbell, J. Y., \& Ammer, J. (1993). What moves the stock and bond markets? A variance decomposition for long-term asset returns. Journal of Finance, 48(1), 3-37.

Campbell, J. Y., \& Shiller, R. J. (1991). Yield spreads and interest rate movements: A bird's eye view. Review of Economic Studies, 58, 495-514.

Campbell, J. Y., \& Shiller, R. J. (1998). The dividend-price ratio and expectations of future dividends and discount factors. Review of Financial Studies, 1, 195-228. http://10.1093/rfs/1.3.195

Choi, J. J., Hiraki, T., \& Takezawa, N. (1998). Is foreign exchange rate risk priced in the Japanese stock market. Journal of Financial and Quantitative Analysis, 33, 361-382. http://10.2307/2331100

Chowdhury, B. (1994). Stochastic trends and stock prices: An international inquiry. Applied Financial Economics, 4 , 383-390.

Corte, S. L., \& Tsiakas, I. (2009). An economic evaluation of empirical exchange rate models. The Review of Financial Studies, 22(9), 3491-3530. http://dx.doi.org/hhn058

Cutler, D. M., James, P. T., \& Summers L. H. (1989). What moves stock prices. Journal of Portfolio Management, 15, 4-12.

De Pace, P. (2013). Gross domestic product growth predictions through the yield spread: Time-variation and structural breaks. International Journal of Finance and Economics, 18(1), 1-24. http://10.1002/ijfe.453

Demarzo, P., \& Duffie, D. (1995). Corporate incentives for hedging and hedge accounting. Review of Financial Studies, 8, 743-771. http://10.1093/rfs/8.3.743

Estrella, A., \& Mishkin, F. S. (1996). The yield curve as a predictor of U.S. recession. Current Issues in Economics and Finance, 2(7), 1-6.

Eun, C. S., \& Shim, D. (1989). International transmission of stock market movements. Journal of Financial and Quantitative Analysis, 24, 241-256. http://10.2307/2330774

Fama, E. F. (1984). The information in the term structure. Journal of Financial Economics, 13, 509-528. http://10.1016/0304-405X(84)90013-8 
Fama, E. F., \& Schwert, W. G. (1997). Asset returns and inflation. Journal of Financial Economics, 5, $115-146$. http://10.1016/0304-405X(77)90014-9

Grisse, C. (2015). The zero lower bound and movements in the term structure of interest rates. Economics Letters, 131, 66-69. http://10.1016/j.econlet.2015.03.039

Hamao, Y. (1988). An empirical examination of the arbitrage pricing theory: Using Japanese data. Japan and the World Economy, 1, 45-61. http://10.1016/0922-1425(88)90005-9

Hamori, S., \& Honda, Y. (1996). Interdependence of Japanese macroeconomic variables. In Yoshiro Ttutsui (Ed.), Japanese capital markets Tokyo, Japan: Nihon-Hyoronsha (in Japanese).

Hirayama, K., Yoshiro, N., \& Tsutsui, Y. (1998). Threshold effect in international linkage of stock prices. Japan and World Economy, 10, 441-453.

Hodrick, R. J. (1992). Dividend yields and expected stock returns: Alternative procedures for inference and measurement. Review of Financial Studies, 5, 357-386. http://10.1093/rfs/5.3.351

Homma, T., Yoshiro, N., \& Tsutsui, Y. (2005). Exchange rate and stock prices in Japan. Applied Financial Economics, 15, 469-478.

Jeon, B. N., \& Chiang T. C. (1996). A system of stock prices in world stock exchange: Common stochastic trends for 1975-1990. Journal of Economics and Business, 43, 329-338. http://10.1016/0148-6195(91)90029-V

Keim, D. B., \& Stambaugh, R. F. (1986). Predicting returns in the stock and bond markets. Journal of Financial Economics, 17, 357-390. http://10.1016/0304-405X(86)90070-X

Kim, D. H., \& Singleton, K. J. (2012). Term structure models and the zero bound: An empirical investigation on Japanese yields. Journal of Econometrics, 170(1), 32-49. http://10.1016/j.jeconom.2011.12.005

Kim, H. (2013). Uncertainty and risk premium puzzle. Journal of Economics and Finance, 37(1), 62-79. http://10.1007/s12197-010-9170-7

Lai, M., Lai, K. S., \& Fang, H. (1993). Dynamic linkages between the New York and Tokyo Stock Markets: A vector error correction analysis. Journal of International Financial Markets, Institutions and Money, 3, 73-96.

Landcon, S., \& Smith, C. E. (2003). The risk premium, exchange rate expectations, and the forward exchange rate: Estimates for the yen-dollar rate. Review of International Economics, 11(1), 144-158.

Liow, K. H., Muhammad, F. I., \& Huang, Q. (2006). Macroeconomic risk influences on the property stock market. Journal of Property Investment and Finance, 24(4), 295-323. http://dx.doi.org/10.1108/14635780610674507

Mazuruse, P. (2014). Canonical correlation analysis: Macroeconomic variables versus stock returns. Journal of Financial Economic Policy, 6(2), 196-179. http://dx.doi.org/10.1108/ JFEP-09-2013-0047

Meric, G. (2012). International evidence on market linkages after the 2008 stock market crash. The International Journal of Business and Finance Research, 6(4), 45-57.

Meric, I., Kimb, J. H., Geng, L., \& Meric, G. (2012). Co-movements of and linkages between Asian stock markets. Bulletin and Economics Research, 3(1), 1-15.

Pincus, M., \& Rajgopal, S., (2003). The interaction of accounting policy choice and hedging: Evidence from oil and gas firms. Accounting Review, 77, 127-160. http://dx.doi.org/10.2308/accr.2002.77.1.127

Pradhan, R. P., Arvin, M. B., Norman, N. R., \& Hall, J. H. (2014). The dynamics of banking sector and stock market maturity and the performance of Asian economics: Time series evidence. Journal of Economics and Administrative Sciences, 30(1), 16-44. http://dx.doi.org/10.1108/JEAS-06-2013-0022

Ruge-Murcia, F. J. (2006). The expectations hypothesis of the term structure when interest rates are close to zero. Journal of Monetary Economics, 53(7), 1409-1424. http://10.1016/ j.jmoneco.2005.07.014

$\mathrm{Wu}$, N.S. (2007). Interest rate risk and the forward premium anomaly in foreign exchange markets. Journal of Money, Credit, and Banking, 39(2-3), 423-442.

\section{(cc) $\mathrm{BY}$}

This work is licensed under a Creative Commons Attribution 3.0 License. 